\title{
Identification Of Managerial Problems Faced By Primary School Head Teachers In Quetta
}

\author{
Rashida Naz \\ \& \\ Sajida Naureen \\ Institute of Education \& Research \\ University of Balochistan \\ Zeenat Sana Baloch \\ Department of Balochi \\ University of Balochistan
}

\begin{abstract}
The primary schools year is an important phase of children education. The objective of this research was to identify the managerial problems faced by Primary Schools Head teachers. For primary data the sample was comprised 10 school heads 100 teachers from the primary schools, questionnaires were distributed among teachers and head teachers. The samples were randomly selected. Results showed that teachers were trying to achieve the students learning outcomes. A large number of head teachers agreed that they knew the process of school management and they were able to control the management of schools. They were trained by the education department regarding primary school management. But on the other hand less number of professional trainings were available for primary school teachers and head teachers. There were some evidences that most of the non-government organizations introduced some training programs for primary school teachers. Most of the head teachers of primary schools faces the shortage of physical and human resources in their schools. A number of head teachers had no qualification related to school management. It was concluded that almost all the in charge and teachers had no clear concept regarding curriculum 2006. Majority of the head teachers had no ability to manage the learning and teaching process. They were found incompetent for report writing and implement their decisions in jurisdiction of school. It was recommended that new posts should be created for head teachers in primary schools and their job description should be cleared. All the incharges or head teachers should be trained in school management and resource management.
\end{abstract}

Keywords: Education Policy, Managerial Problems, Primary School Head Teachers.

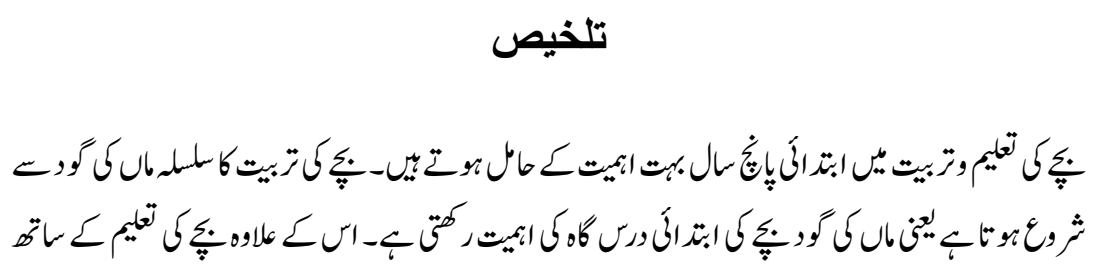




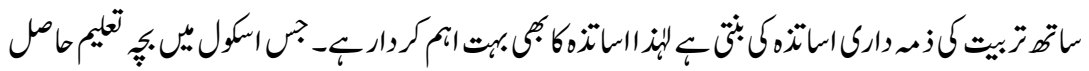

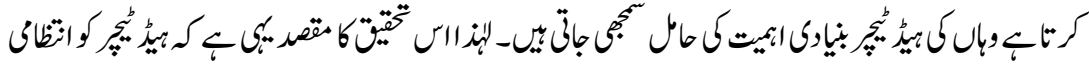

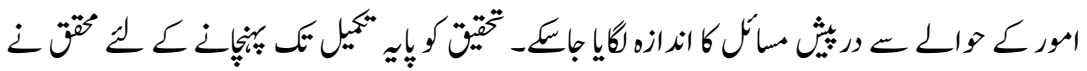

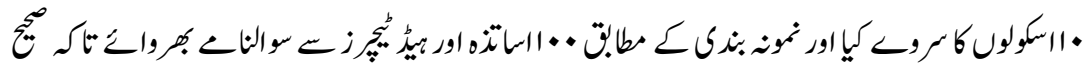

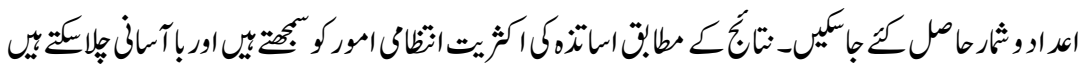

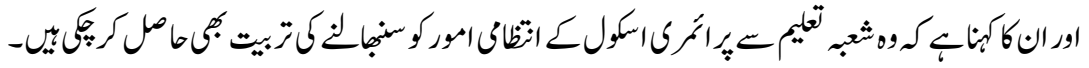

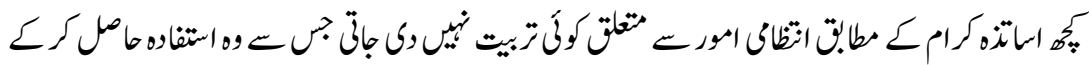

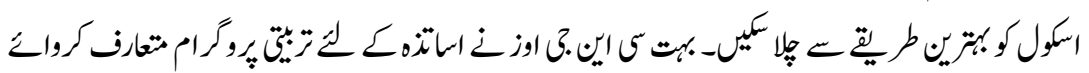

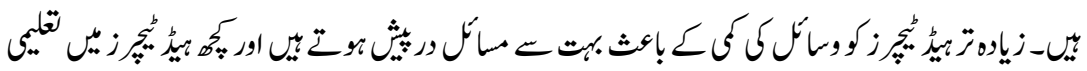

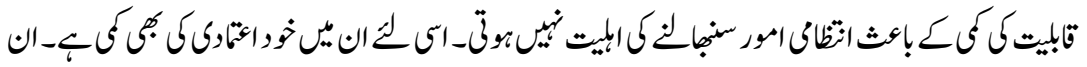

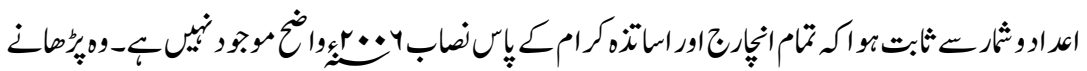

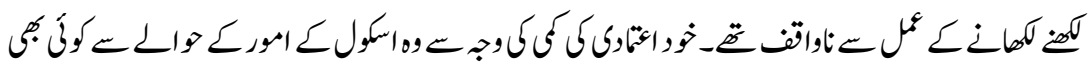

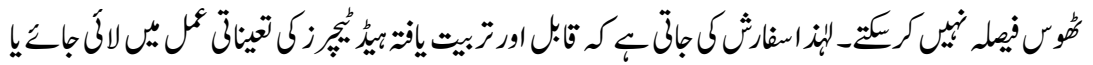

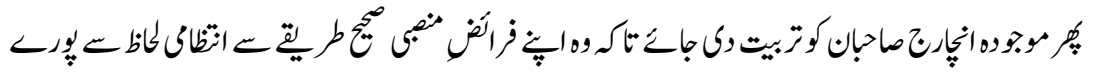

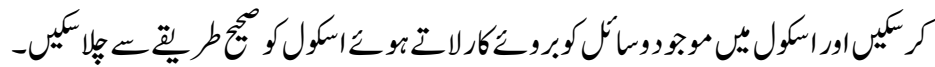

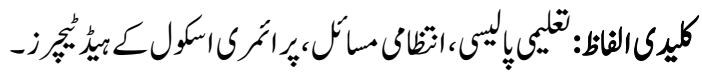

\section{Introduction}

According to UNICEF (2011), Balochistan education system face major challenges like high dropout rate from schools, low enrolment and low survival rate of children. According to data only 23 percent of students move from primary to middle section. At secondary classes the enrolment ratio reduces to $14 \%$. Literacy rate among girls are low as compared to boys education due to lack of basic facilities in primary schools, socio-cultural restriction high dropout rate among girls etc.

In Millennium Summit 2000, all the government from different countries agreed to achieve the targets of MDGs. The Millennium Development Goals, have been adopted by Baluchistan. Regarding education the targets of MDGs are not achieved yet.

The primary schools year is an important phase of children education. Here the parents and teachers want to build every child's confidence and desire to learn. 
The primary school develops in each child $21^{\text {st }}$ century competencies and prepares them equipped with skills to navigate a fast changing world. In primary school, child grows up to become confident person, active contributor and a good citizen and the child develops his knowledge skills, development language and character.

A number of the primary school in Baluchistan consists of 2 to 3 classrooms and mostly two teachers. Only few primary schools have up to five teachers. The senior teacher would be the head of the school, whose responsibilities is to manage the primary school resources and human resource. Mostly primary schools consist of 20 to 150 students. The school heads face many problems regarding low quantity of resources, less sitting space for children etc.

The Primary education in Baluchistan faces a number of problems there problem may be bad infrastructure lack of basic facilities, Untrained teachers etc. The Muslim came in South East Asia with strong education system in the shape of elementary mosque schools. Their education system was based on Islamic ideology. They declared the British Raj changed mass education. The Schooling got relate to the job the education system was related to the political purpose. The colonization of British affected the education system of Muslims. The education was totally neglected by the British rule with the passage of time the east India Company felt the need of education nature than they introduced education in Sub continence (Saeeda, 1999).

As compare the other province the Baluchistan is still struggling to introduce a better primary education system Baluchistan has a dispersed Population with less number of primary school many cosmetic measure have been taken only to raise funds from donor agencies. The primary schools are not supporting the increasing number of student managerial problem, poor monitoring system are the basic reasons behind there satiation.

Primary School management is an important factor each educational level has polices for proper use of resources, the implementation of decision is controlled by the management, the decisions are implemented to produce expected results, the administrative management try to channelize the educational resource and human resource within the school, the manager in Primary school level look after the teaching pedagogies of the teachers and learning of the student. The Primary school manager is also responsible for providing basic education, to develop communication skills and to introduce Islamic thought and transfer of Culture from generation to generation.

Baluchistan is facing with low literacy rate the Primary enrolment ratio is very low about half of the children are out of school the primary school infrastructure and system is not up to date.A Number of gaps exist in the management of 
primary school system also positive change has been observed in mental and social development of primary school children. This study analyzed the managerial problems faced by human resource in primary school of Quetta city. Some of the objectives of the study are as follows:

\section{Objectives}

- To identify the managerial problems, faced by Primary Schools In charge/Heads

- To identify the problem faced by primary school teachers in term of teaching and management.

- It was further to be determined how these managerial problems affected the progress of primary schools.

The finding of study may serve as source of guidance to the In-charge of primary schools. It can also give guidance to education officers and authorities of education department. They may be able to get real knowledge about managerial problem of primary school. The finding of this study may work for the removal of deficiencies exists in primary school managerial problems faced by schools head. The present study is valuable for education department policy makers and for the government of Baluchistan. The study highlights basic managerial Problem in Primary school for community.

\section{Research Questions of the Study}

- What are the basic problems faced by the primary School in charge?

- What strategies are adopted by schools manager to solve to basic issues of primary schools?

\section{Literature Review}

Literacy plays an important role in human development and through this people can fight against poverty. Literacy has a great influence on health, social and economic condition of any state. Literate person have better economic prospect than an illiterate one. The primary school direct affects the primary school student's development. Primary schools can easily change a student into confident person who has a strong sense of the child grow at to become an active contributor who is able to work effectively in team and is innovative, he can also be a self-directed learner who reflects and take responsibility of its own (MICS, 2004).

In Education Reforms, the developed countries have focused on the school management and some organizations have also some contribution. The schools 
have open system; this system has inputs, processes, output and feedback. The most important factors that affects academic quality is its education process and management, and the management depend upon managers, which is head of the school. The school manager is one of the most important factors that affect student achievement. School head have role to shape the teachers development, determine the educational goal and take step to achieve the education objectives (Bunwaree, 2009).

The invention oriented education models depends upon a fruitful cooperation among decision makers and public administration and representatives and organizations related to the scientific society therefore it is more essential for both to work collectively for efficient development and improvement of education system. In this respect major pre-requisites are to be met. The reports related to education are extremely sensitive due to the inherited stress among political interest of administration in representing itself as the best and actual situation of such reporting through which the process of evaluation is presented and priorities are derived for the planning of education. The stress among the administrators of government and decision makers gives an augment of conflicting thoughts among distribution of roles in between both the administrators and decision makers on one side and research entities on other side. a lot of politicians claims the reports are written by civil servants under their personal directions and the scientific society are purely responsible for the production of this data whereas this badly decreases the reporting function and information related to the process of education (Project, A.F, 2007).

The management of education and administration of education are the terms which are being used having the same meaning. In many cases it is referred to the daily routines of head of schools and school principals, whereas in other cases this term is used to indicate two dissimilar functions, executed by two dissimilar offices such as administration and management. In Zimbabwe the school head is the CEO, they are recruited by government, their responsibilities comprised of implementing government rules and obedience and management of human resources and material resources such as to perform both management and administrative jobs (Domike, \& Edward, 2014).

School is consists of employees which includes teaching staff and non-teaching staff and learners and parents each of the personality is having their own expectations, the function of a head of an institute is provide an encouraging environment to enhance common understanding and synchronization among all to work collectively and in collaboration for the promotion of students and school community. The students are main focus towards the mission of school therefore all the related activities should boost to promote the interest. In this regard it is significant to draw attention of students towards the understanding of conclusion 
taken and to have active role making of decisions therefore courage of good quality governance, it is the responsibility of head of institution for having consultation and enlist active participation for the smooth running and better management of schools. The head of the institute and his helpers must work together for making the institute a wide-ranging place collectively for all level of students and provide them the same opportunities for learning together. Human differences being a natural phenomenon so it does also reflects in the school culture. Every person has to be treated optimistic. Equal opportunities has to be provided to all students for participating and sharing in the efforts through an extensive range of working methodology and treatment of individuals (Cheruto, \& Kyalo, 2010).

The study show that in Pakistan there are 158,378 primary schools with a student strength of $17,043,460$ and having 447,890 teachers, out of the total primary schools 37.8 percent schools are not having fences, 32.3 percent are not having facility of drinking water, 56.4 percent are having no electricity, 40.5 percent are having no toilet facility and in 6.8 percent primary schools there is no building. According to the constitution of 1973 all the children are having equality of rights towards liberty of opinion, quality education and right of safety and healthy atmosphere/environment. Global communities focusing and claiming the process of education is a major entrance towards prosperity, social and economic development, harmony, peace, respect for people, law and self-adequacy (Farooq, 2013).

While defining Education Administration policies in Pakistan the distribution of responsibilities between provinces and central government are defined in the constitution of Pakistan 1973, The federal Ministry for education is overall responsible development and management of national policies and plans and programs related to education including the development of curriculum whereas the implementation of these policies local government is responsible. All the provinces are having their own Education Department. The institutions related to education situated in the capital are managed directly by Education Ministry. Pakistan is facing lots of difficulties for the improvement of providing education in 1990s for example inadequate buildings of schools, lack of basic facilities, untrained teachers, Lacking of classrooms, non-availability of textbooks. According to the information by Ministry of Education Pakistan passed law on mandatory education (eight years) (Norric, 2006).

\section{Methodology}

The study was qualitative in nature and focused on primary data. The primary source of data was analyzed for the study. The sample was comprised 10 school heads and 100 teachers from the primary schools. The sample was randomly collected. Data 
was collected through two different type of questionnaire. One questionnaire was prepared for school head teachers (incharge) and second for teachers.

\section{Research Method}

This study was qualitative in its nature. Two types of questionnaire were the research tools for the study. The following were the respondents for the study; Head Teachers (Primary Schools Incharge) and Primary School Teachers. The primary schools of district Quetta was total population for this research and ten primary schools incharge and hundred primary school teachers were sample size. The study was limited to government boy's and girl's primary school of Quetta City. This topic has a great importance and it was necessary to find out the managerial problem. The role of primary schools has direct impact on children cognitive, physical and emotional development.

\section{Analysis and Results}

The results of the question regarding managerial problem reveals that the basic managerial problems that the head teachers were facing during their school's duty were as followings; There were very few proper buildings for schools, so the classes were not enough for the students, the head teachers faces overcrowded classes. Secondly community people doesn't co-operate with teachers and head teachers regarding the repairing of schools building. There were limited number of teachers in most of the primary schools; There were shortage of teachers specially for the subject of English and Math. In most of the schools, absence of peons and sweepers were common, the problem of convince was also the major problem faced by head teachers, Basic facilities were not available such as water, gas and electricity. No trainings regarding management of primary schools were given to the teachers and head teachers; most of the time no funds were given to the educational authorities and funds were not distributed equally. Absentees of students and teachers impact the schools performance. According to the results mostly schools were situated in urban areas, the people were illiterate and there was a great problem of communication among parents and teachers. Due to poverty, students were not having proper uniform and shoes, they couldn't afford the expend ties of school like books, bags and stationary. This situation affected the performance of teachers and head teachers.

The result of question about resolving the problems explore that majority of the people said that mostly DDOs are responsible to resolve the problems of the schools. That majority of participants said that Government should approve new buildings for the students so more and more buildings must be constructed in the schools to overcome with the problems of classrooms. Convince facilities should be provided to the students and teachers specially buses, check and balance on the authorities whether they are working properly or not, Funds should be provided on time. The school administration must organize parents' teacher meetings on regular 
bases. More teachers must be appointed to overcome with the problem of teachers. Trainings for the staff should be arranged so they can have more trained faculty.

The analysis of the questions regarding suggestions to improve the management of schools reveals that most of the participant's responses were that more trainings should be given for the management of schools, different programs must be organized to enhance the qualities of students, co-operation among parents and teachers regarding to the progress of students. Funding must be provided, Qualification of the teachers is not enough according to their posts more qualified teachers should be appointed. The over age teachers do not give quality time to their students. Trainings regarding curriculum should be given to the teachers. The problem of peons must be overwhelmed and last the problem of convince should be observed because of bad weather in the province students face difficulties for the outback so more vehicle should be provided from the side of Government to overcome with the problem of convince.

\section{Discussion}

The role of Primary School management can't be ignored. Thousands of primary schools are functioning in urban and rural areas of Baluchistan. The Government of Baluchistan is extremely interested to open a new Primary Schools in Suburb areas and to appoint fresh human resource belong to the same communities. Most of the Primary Schools consisted of two to three classrooms with three to five teachers, beside this a number of schools having single teachers. The main job of the Primary head teachers or incharge is to manage the physical and human resources of school. According to results most of the head teachers were satisfied with their teacher's performance. They were on the view that teachers are trying to achieve the students learning outcome from the targeted groups. A large number of head teachers agreed that they knew the process of school management and they were able to control the management of schools. They were trained by the education department regarding primary school management. But on the other hand less number of professional trainings was available for primary school teachers and head teachers. There were some evidences that most of the nongovernment organizations introduced some training programs for primary school teachers. Most of the primary schools face the shortage of physical and human resources. Most of the female participate agreed that they know resource management but male participants were not agreed. A number of teachers had no qualification related to school management. The qualification of aged teachers was matric and intermediate. Some teachers had completed their professional degree i.e. B.Ed. and M.Ed. The performance of qualified teachers was better than non-qualified teachers. The curriculum of B.Ed. and M.Ed having school management and resource management contents. Approximately 16 to 20 subjects 
are thought in B.Ed. and M.Ed to most of the subject was related to school management.

\section{Conclusions}

Balochistan is a largest province of Pakistan and it has a dispersed population. A large number of primary school having two to three classrooms, a small number of washroom, and faces a shortage to drinking water. A primary schools incharge was among the three or four JVT teachers in school. No permanent post of incharge existed in such primary schools. Management needs professionally sound people having the basic knowledge of school management. But for primary school incharge, no refresher course or training program was introduced by education department for the professional development of primary school teachers and head teachers regarding school management. How to manage the resource, how to make sure the availability of safe drinking water, how to manage the sewerage system, how to assess the teachers teaching pedagogies, how to control the dropout rate in schools were the basic problems of primary schools. Practice of corporal punishment, attitude of teachers toward students and head teachers, Absentees of teachers in rural area, were the other problems. It was found that there was no special or annual budget for the proper running of primary schools. These problems directly affected the performance of schools manager. The school managers were satisfied with their management but their knowledge were very low and they were not up to date.

If was also concluded that almost all the incharge and teachers had no clear concept regarding curriculum 2006. Curriculum 2006 is the currently implemented curriculum for primary and secondary school. A project was launched by USAID for the implementation and introduction of national curriculum in Baluchistan. But above mentioned project was introduced in twelve districts of Province. The primary school teachers had no clarity about updated curriculum. Even most of the teachers did not know about major objectives of curriculum and education. Majority of the head teachers had no ability to manage the learning and teaching process according to curriculum 2006. They were unable to formulate a checklist for the monitoring of educational activities with in the primary schools. They were found incompetent for report writing and implement their decisions in jurisdiction of school.

\section{Recommendations}

- New posts should be created for head teachers in primary school and their job description should be cleared.

- All the incharges or head teachers should be trained in school management and resource management.

- A special training program should be introduced by education department regarding curriculum 2006 for teachers and head teachers. 
- A budget should be provided on annually basis for primary schools in Quetta.

- A strong communication system should be built between all the stakeholders of education department.

- The primary schools should be encouraged in cluster program and handsome capital should be provided to primary schools.

- The primary education should be separated form secondary education. A separate directorate should be functional for primary section.

- All non-government organizations should introduce new project for the capacity building of head teachers regarding school management.

\section{References}

Ahmed, I., Muhammad, R., Aqeela, R. ,Shahfiq, ur R. \& Muhammad, S. (2013). Analysis of the Problems of Primary Education System in Pakistan, Critical Review of Literature, Academic Research International, vol.4:2, p.2.

Ahmed, I. \& Mujahid (1991). A Study of School Facilities, Teacher Characteristics, Class Resources and Teaching Practices as Related to Access, Retention and Dropout of Children in Kachi Classes of Quetta, Sibi and Loralai districts of Balochistan, Primary Education Development Program Balochistan, Quetta, pp.7-8.

Aijaz, S.M. (2002). Learning Achievement in Primary Schools of Pakistan, UNESCO Islamabad in Collaboration with Ministry of Education Curriculum Wing, Government of Pakistan, Published by UNESCO, p.13.

Anjum, M.S., Zafar. I. \& Uzma, R. (2012). Identification of Problems Faced by Heads of Teacher Education Institutions in Achieving New Millennium Goals. International Journal of Social Sciences and Education, vol.2, pp.30-31.

Australian Government, Productivity Commission. (2013). On Efficiency and Effectiveness: Some Definitions, Australian Government, Productivity Commission, Staff Research note in May 2013. (p.1)

Aziz, M. (2014). Education System Reform in Pakistan: Why, When and How? (Children's Global Network, Pakistan), David E. Bloom (Harvard School of Public Health and IZA), SalalHumair (Harvard School of Public Health), Emmanuel Jimenez (IEG, World bank), Larry Rosenberg (Harvard School of Public Health), ZebaSathar (Population Council, Pakistan) Policy Paper No 76. Published by IZA, pp.3-4\&9. 
Baluchistan Education Sector Plan. (2012). Outlined Document, Developed by PPIU, Education Department, Government of Baluchistan. pp. 1-26.

Bunwaree, V.K. (2009). School Management Manual, Policies, Procedures and Guidelines on School Management Issues, Produced by: School Management Division. Ministry of Education, Culture and Human Resources in August 2009, pp.4-5.

Cheruto, K.L. \& Kyalo W. B. (2000). Management Challenges Facing Implementation of Free Primary Education in Kenya. A Case Study of Keiyo District. Journal of Education Administration and Policy Studies, vol.2:5, pp.71-76.

Dearden, R.F. (2010). The Concept of Play: The Concept of Education, Routledge, New York, vol.17, pp.51-62.

Domike, G.C, \& Edward, O. O. (2014). An Evaluation of Major Implementation Problems of Primary School Curriculum in Cross River State, Nigeria, Department of Curriculum and Teaching, University of Calabar, Research Paper: American Journal of Educational Research, vol.2:6, pp.397-401.

Education and Manpower Bureau. (2003). Primary Education the Administration of Primary Schools: Published by the Education and Manpower Bureau and Education Department in January 2003, Hong Kong, p.5-6.

Farooq, M.S. (2013). An Inclusive Schooling Model for the Prevention of Dropout in Primary Schools in Pakistan, Bulletin of Education and Research, vol.35:1, pp.47-74.

Hamlyn, D.W. (2010). The Logical and Psychological Aspects of Learning, The Concept of Education, Routledge, New York, vol.17, pp.17-30.

Khan, A.S. (2009). Policy Analysis of Education in Baluchistan, Compilation and Analysis by Abdul Sami Khan for UNESCO Islamabad, Pakistan in November 2011 (National Professional Standards for Teachers in Pakistan, Policy and Planning Wing, Ministry of Education, Government of Pakistan, 2009) pp.40-52.

Memon, G.R. (2007). Education in Pakistan: Key Issues, Problems and the New Challenges, Journal of Management and Social Sciences, vol.3:1, pp.48-54.

MICS. (2004). The Problems of Primary School Managment, Primary Education in Developing Countries, Survey Report, United Nation Children Fund, p.4. 
Mtetesha, N .(2013). Monitoring \& Evaluation in Education, www.academia.edu, vol.1, p.1.

NCHD \& UNESCO (2011). Education for All Plan Balochistan 2011-15, Directorate of Education, Government of Balochistan, Developed by: Education Department, Government of Balochistan in collaboration with NCHD and UNESCO, p.30.

Norric, (2006). The System of Education in Pakistan. Nordic Recognition Information Center, October 2006, published by Norric, Sources: The World Fact Book. Pakistan. CIA, 2006, National Education Policy (19982010) Ministry of Education, Pakistan, p.6.

Paul H. H. (2010). The Logical and Psychological Aspects of Teaching a Subject: Knowledge and the curriculum, A Collection of Philosophical paper, M.Phil Papers, 2010, vol-17, pp.33, 35, \& 37.

Peter, R.S. (2010). The Concept of Education, Published in the Taylor \& Francis e-Library, International Library of the Philosophy of Education, London, ROUTLEDGE and KEGAN PAUL,2010, vol-17, pp.1-4, 6.

Projekt, A.F. (2007). Principles of Cooperation between Educational Policy, Government Administrations and Scientific Research: Und Network management, Berlin, Publication: OECD/CERI Regional Seminar of German speaking countries in the year 2007, pp.43-44.

Rehman, M. \& Haleema, B. (2013). A Study of Administrative Issues in Secondary Schools of Quetta, Part-11: Social Sciences and Humanities, vol.4:3, pp.299-301.

Retallick, J. (2005). Managing School Success: A Case Study from Pakistan by Agha Khan University, Institute for Educational Development, Karachi. Published by The Agha Khan University January 2005. Leading and Managing, vol.11:1, pp.32-42.

Ryle,G. (2010). Teaching and Training: Journal for the history of Analytical Philosophy, University of Illinois at Chicago, vol.17, pp.73-82.

Saeeda, S. (1999). Positioned as Women Educational Leaders in a Muslim Society. Education Management: Braving Boundaries; National Book Foundation: Islamabad,. Pakistan. p.08. 
Samkange, W. (2013). Management and Administration in Education: What do School Heads Do? A Focus on Primary School Heads in One District in Zimbabwe. International Journal Social Science and Education 2013, vol-3, pp.635-636.

Shah, D. (2004). Monitoring the quality of Secondary Education in the Contact of Decentralization in Pakistan.

SigPorsson, R. (1995). Leading Improvement in Small Schools, A Comparative Stud

y of Headship in Small Primary Schools in Iceland and England, A Thesis submitted by the M.Phil Degree in School Development, University of Cambridge Faculty of Education, pp. 1-4,7-14.

Tanzania Education Sector, (2008). Primary and Secondary Education Management Issues: Published: Tanzania Education Sector analysis in September 2008, p.269.

UNESCO. (2011). Systematic Monitoring of education of all Training modules for Asia-Pacific, p.6.

UNICEF. (2011). District Development Profile, Quetta, by Planning and Development Department, Government of Balochistan in Collaboration with UNICEF, pp. 72,106.

UNICEF. \& IDO. (2015). Baluchistan EMIS Strengthening and Institutionalizing of Education Management Information System (EMIS). A project by Department of Education with the support of UNICEF and technical Implementation Partner (IDO), pp.1-4.

Vazir, N. (2008). Exploring Current Practices of supervisors in government primary schools in Karachi, Pakistan, Journal of educational research Volume-11 No.1 2008 Department of Education IUB, Pakistan by Agha Khan University, Institute of Educational Development, Karachi and Noor Hussain (Professional Development Teacher, Primary Education, Government of Sindh, Khairpur) pp.37-38.

Yasar, S. (2008). Classroom Management Approaches of Primary School Teachers. The graduate School of Social Sciences of Middle East Technical University, Department of Educational Sciences, September 2008, pp.1-65. 
Rashida Naz is M.Phil Research Scholar in the Institute of Education \& Research, University of Balochistan.

Dr. Sajida Naureen is an Assistant Professor in Institute of Education \& Research, University of Balochistan.

Dr. Zeenat Sana Baloch is Professor in the Department of Balochi, University of Balochistan. 